\title{
The Impact of the COVID-19 Pandemic on Student Learning Motivation
}

\section{* Putu Dharma Komala Suarsi' ${ }^{1}$ I Made Citra Wibawa ${ }^{2}$}

1,2 Program Studi Pendidikan Guru Sekolah Dasar, Ganesha University of Education, Singaraja, Indonesia

\section{ART ICLE IN F O}

Article history:

Received March 11, 2021

Revised April 17, 2021

Accepted April 30, 2021

Available online May 25, 2021

Kata Kunci:

Media Video Animasi, Project

Based Learning

Keywords:

Animation Video Tutorial, ProjectBased Learning

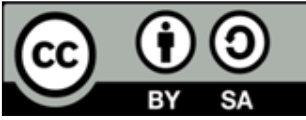

This is an open access article under the CC BY-SA license.

Copyright (@) 2021 by Author. Published by Universitas Pendidikan Ganesha.

\begin{abstract}
A B S T R A K
Pandemi COVID-19 menimbulkan dampak dalam berbagai bidang tidak terkecuali pendidikan. Salah satu upaya pemerintah untuk memutus mata rantai penyebaran COVID-19 yaitu melaksanakan kegiatan pembelajaran dapat dilakukan secara online untuk semua jenjang pendidikan. Penelitian ini bertujuan untuk menganalisis dampak pandemi COVID-19 terhadap motivasi belajar siswa kelas IV SD. Jenis penelitian ini adalah penelitian deskriptif, dengan teknik kuantitatif dan kualitatif. Populasi penelitian ini adalah seluruh siswa kelas IV di Sekolah Dasar yang berjumlah 186 orang siswa. Penentuan sampel menggunakan teknik sample jenuh sehingga sampel yang digunakan dengan jumlah 186 orang siswa. Data penelitian diperoleh menggunakan metode nontes yaitu dengan pedoman wawancara dan instrumen dalam bentuk angket skala likert motivasi belajar siswa. Data hasil penelitian dianalisis dengan metode analisis statistika deskriptif. Berdasarkan hasil analisis diperoleh bahwa proses pembelajaran di kelas IV SD selama pandemi COVID-19 dilaksanakan secara kombinasi antara daring dan luring. Analisis data angket motivasi diperoleh bahwa rata-rata motivasi siswa yaitu 79,71 berada dalam kategori kurang/rendah. Maka, dapat disimpulkan bahwa pandemi COVID-19 memberikan dampak terhadap motivasi belajar siswa menjadi rendah.
\end{abstract}

\section{A B S T R A C T}

The COVID-19 pandemic has had an impact in various fields, including education. One of the government's efforts to break the chain of spreading COVID-19 is to carry out learning activities online for all levels of education. This study aims to analyze the impact of the COVID-19 pandemic on the learning motivation of fourth grade elementary school students. This type of research is descriptive research, with quantitative and qualitative techniques. The population of this study were all fourth grade students in elementary school, amounting to 186 students. Determination of the sample using saturated sample technique so that the sample used is 186 students. The research data were obtained using the non-test method, namely with interview guidelines and instruments in the form of a Likert scale questionnaire for student learning motivation. The research data were analyzed using descriptive statistical analysis methods. Based on the results of the analysis, it was found that the learning process in grade IV SD during the COVID-19 pandemic was carried out in a combination of online and offline. Analysis of the motivation questionnaire data showed that the average student motivation, namely 79.71, was in the low category. So, it can be concluded that the COVID-19 pandemic has a negative impact on student learning motivation.

\section{INTRODUCTION}

Education is a process of mutual adjustment either receiving or giving knowledge, with this adjustment it is hoped that it will provide changes in humans (Anwar, 2015; Nurkholis, 2020). On January 30, 2020, WHO declared the disease outbreak in China COVID-19 a Public Health Emergency of international concern (Sohrabi, et al, 2020; Song \& Karako, 2020; Susilo et al., 2020; Talevi et al., 2020). The spread of COVID-19 is very fast, which has resulted in various countries implementing isolation, (Smith, A. W., \& Freedman, 2020; Yuliana, 2020). In addition, many countries are maintaining physical distance to reduce the rate of spread of the virus (Koh et al., 2020; Marroquín et al., 2020). In Indonesia, the impact of the COVID-19 virus occurs in various fields, such as social, economic, tourism, and education is no exception. The emergence of the COVID-19 virus has had a huge impact on the world of education. 
The impact of COVID-19 is felt by several parties, namely teachers, school principals, students and parents (Mastura dan Rustan Santaria, 2020; Pajarianto et al., 2020).

In an effort to stop the spread of COVID-19 so that activities can run normally again, especially for the world of education, the Government issued a Circular of the Minister of Education and Culture of the Republic of Indonesia No.4 of 2020 concerning Implementation of Education Policies in an Emergency for the Spread of COVID 19. With the closure of schools or implementation Distance learning results in students not being able to interact with their peers, and teachers (Nurkholis, 2020). Learning from home is better known as distance learning which combines the principles of the learning process with technology (Cucu, 2016). Distance learning can use several online applications such as classrooms, video conferencing, zoom, and whatsapp groups to support communication and interactions during learning and learning can be carried out at a more flexible time and place. (Gunawan, G., Suranti, N. M. Y., \& Fathoroni, 2020; Umar, 2020; Zaharah, 2020).

Distance learning can use two methods, namely online and offline learning. Online Learning can be held through a web network with an unlimited number of participants using various technological media (Bilfaqih, 2015; Dabbagh and B. Bannan Ritland, 2007; Putria, 2020; Rigianti, 2020). Online learning is in accordance with local situations and conditions to create effective and comfortable learning for students in the midst of the COVID-19 pandemic (Herliandry, Devi ., 2020; Zhang et al., 2020). While offline learning can be done not connected to the internet network or using media such as radio, television or face-to-face systems (Ambarita, 2021). Distance learning raises various problems. The problem during online learning is that the teacher has difficulty controlling and maintaining the learning atmosphere because it is limited in virtual space, the concentration and motivation of children learning from home and at school will certainly be different, students feel bored for too long not meeting with their teachers and friends, not all students have learning support facilities such as cellphones or laptops, the lack of knowledge of teachers, students and parents regarding the use of technology, and other problems occur in the assessment process and the opportunity to get a job after graduating from education (Aji, 2020; Anugrahana, 2020; Cahyani, 2020).

This problem also occurs in fourth grade students of SD Cluster IX, Buleleng District, namely learning during the COVID-19 pandemic has caused various problems, namely the results of student work become diverse and not as expected by the school, lack of parental assistance to help and facilitate the learning process, students experience difficulty adapting to distance teaching and learning activities. This will indirectly have an impact on the motivation of students in learning. The existence of good motivation in learning will show good results (Mediawati, 2010). Motivation to learn is very much needed during the COVID-19 pandemic because with student learning motivation, it can provide enthusiasm for learning and direct learning activities better, besides that with one's motivation will get better considerations in learning activities. The existence of learning motivation can also provide an impetus to make changes in achieving goals (Emda, 2017; Garavan et al., 2010; Sukiyasa, 2013). Motivation to learn is one of the main principles for efficient education (Kim, 2011). Based on the description above, it is important to conduct descriptive research regarding the impact of the COVID-19 pandemic on student learning motivation in elementary schools.

\section{METHOD}

This research is a type of descriptive research. Descriptive research is a multiple method in focus with an interpretive approach to each subject matter (Gumilang, 2016). This type of descriptive research used in this study intends to see, review and draw conclusions to obtain information about the impact of the COVID-19 pandemic on student learning motivation in primary schools. The research was conducted in elementary schools, namely as many as 9 schools, carried out in grade IV. The data collected is the learning motivation data of the fourth-grade students. This research was conducted in 3 (three) stages, namely the initial stage of research, the stage of research implementation and the final stage of the study. The initial stage of the research was carried out by arranging permits related to the implementation of research in cluster IX elementary schools, Buleleng District, Academic Year 2020/2021, the preparation of research instruments. The instrument used in this research is a questionnaire / questionnaire. conduct trials on the instrument, and test the validity and reliability. The research implementation stage was carried out by collecting data using a questionnaire given to students to find out student motivation during distance learning, interviews were conducted with grade IV teachers to find out how the learning process was during the COVID-19 pandemic, and data from management results were then analyzed by experts related to the instrument. The final stage of the research is the preparation of a research report and presentation of the research results. In this study the population was all fourth grade students of elementary school in cluster IX, Buleleng district, with a total of 186 students. To determine the sample, 
the research was carried out with saturated sampling technique. Saturated sampling is a sampling technique using the entire population as a sample (Unaradjan, 2019). The sample of this study was 186 students of grade IV SD to obtain student learning motivation. Interviews were conducted with 9 grade 4 elementary school teachers to obtain information related to the learning process during the COVID-19 pandemic. And the motivation questionnaire is used to measure the level of student learning motivation.

The data collection method used in this study is a non-test method with instruments in the form of a student learning motivation questionnaire. In this study, the indicators of learning motivation were used to use. The arrangement of motivational instruments is based on the grid that has been arranged based on indicators which have been modified, namely the duration of learning, attitudes towards learning, the desire and desire to succeed, the encouragement and need in learning, the existence of hopes and aspirations for the future, the appreciation in learning, the existence of interesting activities in learning, the existence of a conducive learning environment. which allows students to learn well (Hanafiah \& Cucu, 2012; Uno, 2011). The questionnaire grid is shown in Table 1. The questionnaire grid is used to make it easier to find out the level of learning motivation of fourth grade students in elementary schools. The test grid is presented in a tabular form containing indicators, statement item numbers, and number of items for each measured indicator. There are 30 statement items, the questionnaire scoring uses a Likert scale. In using this scale, respondents agree or disagree with a number of statements related to the object of the researcher. Scores on the Likert category scale, answers are given quantitative values of 5, 4, 3, 2.1. In order for the instrument to be made to meet good requirements, an expert assessment (judges) is carried out before being designated as an instrument for further research. The research instrument was analyzed using the validity test, reliability obtained 26 valid statement items and 4 invalid statements. Data analysis methods and techniques used in this study were qualitative descriptive statistics and quantitative descriptive statistics. Qualitative descriptive statistical analysis is used in interview results and quantitative descriptive statistics is used in motivation learning.

Table 1. Student Motivation Questionnaire Grid

\begin{tabular}{|c|c|c|c|}
\hline \multirow[t]{2}{*}{ Learning Motivation Indicator } & \multicolumn{2}{|c|}{ Item Number } & \multirow[t]{2}{*}{ Total } \\
\hline & Positive & Negative & \\
\hline Study duration & 1 & 2 & 2 \\
\hline Attitude towards learning & 3 & 4 & 2 \\
\hline There is a desire to learn & 6,7 & 5,8 & 4 \\
\hline There is a need for learning & $9,10,11$ & 12,13 & 5 \\
\hline $\begin{array}{l}\text { There are hopes and dreams for the } \\
\text { future }\end{array}$ & $14,15,16,17,18$ & 19 & 6 \\
\hline There is an appreciation in learning & $20,21,22,23$ & 24 & 5 \\
\hline $\begin{array}{l}\text { There are interesting activities in } \\
\text { learning }\end{array}$ & 26 & $25,27,28$ & 4 \\
\hline $\begin{array}{l}\text { The existence of a conducive learning } \\
\text { environment that allows one to study } \\
\text { well }\end{array}$ & 30 & 29 & 2 \\
\hline
\end{tabular}

(modified from Hanafiah \& Cucu, 2009 and Uno , 2011)

\section{RESULT AND DISCUSSION}

Based on the results of the study, information was obtained that the learning process in class IV of Cluster IX, Buleleng District was carried out in a combination of online and offline. Learning implementation activities have been running properly according to the standards of the learning process during the COVID-19 pandemic. This learning is carried out by the teacher for the first time so that it is said to be not optimal. This is because teachers, students, schools and parents experience several obstacles. Obstacles experienced by teachers such as mastery of information technology by teachers and students, inadequate facilities and infrastructure, and limited internet access, assessment, choice of learning media, and delivery of learning materials (Aji, 2020; Dewi, 2020; Jena, 2020). Less optimal learning is also caused by the lack of discipline of students doing assignments, there are some students who do not do it at all so that the teacher has to give additional time. Students do not have their own cell phones, so the information given by the teacher is sometimes late to the students because they have to wait for their parents to come home from work. Parents have difficulty balancing responsibilities, providing motivation, gaining access, and evaluating their children's learning outcomes (Garbe et al., 2020). When assessing the learning process the teacher also experiences difficulty in providing assessments to students. The results of the assignments given by students were not as expected. Aspects 
of assessment such as attitudes, knowledge and skills cannot be implemented optimally. In addition, there are some students who do not collect assignments so that the teacher provides standard scores, student participation during learning is still lacking. The learning process during the COVID-19 pandemic affects student learning motivation. Based on the results of the student learning motivation questionnaire. Based on the analysis of student learning motivation questionnaire data, the level of learning motivation of grade IV SD Cluster IX, Buleleng District during the pandemic obtained an average result (mean) of 79.71. The tendency of students' motivation to learn during the COVID-19 pandemic was in the "poor" category, which was in the range 72-81.

Table 2. Learning Motivation Based on a Likert Scale

\begin{tabular}{lll}
\hline Criteria & Number & Classification \\
\hline$M_{i}+1,5 S D_{i} \leq M \leq M_{i}+3,0 S D_{i}$ & $100 \leq X \leq 115$ & Very good \\
$M_{i}+0,5 S D_{i} \leq M<M_{i}+1,5 S D_{i}$ & $91 \leq X \leq 100$ & Good \\
$M_{i}-0,5 S D_{i} \leq M<M_{i}+0,5 S D_{i}$ & $81 \leq X \leq 91$ & Enough \\
$M_{i}-1,5 S D_{i} \leq M<M_{i}-0,5 S D_{i}$ & $72 \leq X \leq 81$ & Less \\
$M_{i}-3,0 S D_{i} \leq M<M_{i}-1,5 S D_{i}$ & $57 \leq X \leq 72$ & Very less \\
\hline
\end{tabular}

Students' motivation to learn while participating in distance learning during the COVID-19 pandemic has a low level of motivation. This is influenced by several factors, namely first, the duration of the study time. The long duration of study will have a positive impact on students (Titis \& Sari, 2019). The learning process during the pandemic has resulted in low student learning duration. Second, attitude towards learning, during the COVID-19 pandemic the attitude is happy to carry out distance learning and enjoy using various distance learning media applications (Umar, 2020). However, some students are not happy with distance learning. This is because students do not understand the material, feel overwhelmed by the assignment given, cannot interact with friends or teachers and students are very bored studying at home only doing assignments and learning is not interesting. (Asmuni, 2020). Third, there is a desire and desire to learn. Students have a strong desire to successfully participate in learning activities (Maiti \& Bidinger, 2021). As well as trying to get high scores in learning activities even though they are carried out in online learning. In line with Drago states that students who take online learning have strong learning styles in terms of reading and writing and visuals (Mastura dan Rustan Santaria, 2020). During the COVID19 pandemic students feel easily discouraged and lazy to do assignments when experiencing difficulties. Difficulty in adapting causes the students' absorption of any given material to experience differences and become slower. This condition is because students do not understand the material and students also lack assistance in learning (Dewi, 2020).

Fourth, there is a need for learning. Students who have an interest in learning, students will follow the learning process well, and feel happy (Suprihatin, 2015). So those students consider that learning is not only an obligation but learning is a necessity. The distance learning process (PJJ) during the COVID-19 pandemic can still accommodate the learning needs of students as an effort to develop talents and interests and knowledge according to their educational level (Basar et al., 2021). Online learning provides a more learning experience, through text, audio, video and animation (Arnesti \& Hamid, 2015). However, the fact is that distance learning in class IV SD Cluster IX, Buleleng District during the pandemic has resulted in students experiencing difficulties in learning such as students waiting for parents' help in finding material, accessing videos and inadequate facilities, this causes students to be less enthusiastic and lazy looking for information related to assignments, so that students collect assignments not on time. Fifth, there are hopes and dreams for the future. There are hopes and aspirations of the future that must be achieved, it will cause the desire to continue to learn and improve their abilities (Widlund et al., 2020). This can be seen from students who have clear goals and images related to their future, such as students who are not ashamed to ask questions if they do not understand during distance learning, do not delay in doing assignments, are still active in studying even though they are studying online, and students study seriously so that they do not understand. easy to reach goals in the future (Rumhadi, 2018). However, the reality is that not all of them are happy to learn online and offline, in class IV of the Cluster IX Elementary School in Buleleng District, students prefer to study face-to-face at school. Some students at home studying only the wishes of their parents, and students often delay collecting assignments, this is very influential on their learning motivation. This shows that students' hopes and aspirations for the future have decreased due to changes in learning processes during the COVID-19 pandemic.

Sixth, there is an appreciation in learning. Rewards are an easy and effective way to increase student motivation (Oktiani, 2017; Saptono, 2016). This can be seen from the students doing their assignments seriously and on time. Tasks that are done well, students will get good grades, besides that 
students who get good grades will get prizes in the form of praise from teachers and parents, so that students will be more eager to learn (Sahiu, \& Wijaya, 2017). Based on the results of research, some students during the COVID-19 pandemic did not study at home even though they were punished by their parents, besides that teacher rarely give awards to students, besides that, students are bored learning just by doing assignments given by the teacher without any interaction with other students and parents cannot fully assist them during online and offline learning. This condition needs to be a concern for all components involved in the learning process. Seventh, there are activities that are interesting in learning. Interesting learning activities will create a more meaningful atmosphere and learning process. Meaningful learning is learning that will always be remembered, appreciated and understood (Najib, 2016). Like the learning process using various instructional video media to convey material during learning. However, the fact is that students are not happy learning to use video. Students also get bored easily learning using videos. This is due to the limited ability of students to use facilities such as cellphones or laptops and not all students have these facilities (Quezada et al., 2020). The internet network becomes an obstacle when playing videos and looking for learning materials and videos that are less attractive to students.

Eighth, there is a conducive learning environment. A conducive learning environment is one of the driving factors for student learning to enable someone to learn well (Uno, 2011). During the COVID-19 pandemic students carry out the learning process in their respective homes, the learning environment at home and school is clearly different. Students will feel comfortable in a learning environment such as a quiet home learning environment, and a clean learning place (Purwanto, 2020). However, some students still found it more difficult to understand the material and did not focus during distance learning. This is because the environmental conditions at home are not conducive, and the place to study is less comfortable. Previous research regarding student learning motivation during the COVID-19 pandemic, the results obtained from an analysis of a percentage of $66 \%$. These results are included in the motivated category but are not optimal (Nita, 2020). Student motivation during the pandemic was due to external encouragement, namely encouragement from parents and teachers so that students were motivated to participate in distance learning. Research conducted regarding the impact of learning from the COVID-19 pandemic on student learning motivation, the results stated that the COVID-19 pandemic had a significant impact both in terms of economy and education (Robandi \& Mudjiran, 2020). Based on the results of the study it was found that $11 \%$ of students' learning motivation in online-based learning was in the very high category, $38 \%$ of the students were in the sufficient category, $27 \%$ of the students were in the medium motivation category and $24 \%$ of the students were in the low motivation category. From these results it can be seen that the achievement of learning motivation results has not been maximal, so that efforts need to be made to increase student learning motivation so that it becomes more optimal..

\section{CONCLUSION}

Learning implementation during the COVID-19 pandemic was carried out in a combination of online and offline. The implementation of learning during the COVID-19 pandemic has an impact on student learning motivation to be low. This is because during learning teachers, students, parents and institutions experience various obstacles such as the ability to use technology, difficulties for students to understand material, learning support facilities, learning evaluation and the participation of some students in learning during the COVID-19 pandemic is still lacking so that the COVID-19 pandemic. -19 has an impact on the learning process to be not optimal. Some of the obstacles faced by students can be used as evaluation material for educators in realizing how important it is to motivate students and it is important to improve self-quality so that they can carry out better learning activities so that educational goals can be achieved in the COVID-19 pandemic situation properly.

\section{REFERENCES}

Aji, R. H. S. (2020). Dampak Covid-19 pada Pendidikan di Indonesia: Sekolah, Keterampilan, dan Proses Pembelajaran Dampak Covid-19 pada Pendidikan di Indonesia: Sekolah, Keterampilan, dan Proses Pembelajaran. Jurnal Sosial \& Budaya Syar-I, 5(1), 395-402. https: //doi.org/10.15408/sjsbs.v7i5.15314.

Ambarita, J., Jarwati, S. P. K., \& Restanti, D. K. (2021). Pembelajaran Luring. Penerbit Adab.

Anugrahana, A. (2020). Hambatan, Solusi dan Harapan : Pembelajaran Daring Selama Masa Pandemi Covid-19 Oleh Guru Sekolah Dasar. Jurnal Pendidikan Dan Kebudayaan, 10(3), 282-289. https://doi.org/10.24246/j.js.2020.v10.i3.p282-289.

Anwar, M. (2015). Filsafat Pendidikan. Kencana.

Asmuni, A. (2020). Problematika Pembelajaran Daring di Masa Pandemi Covid-19 dan Solusi 
Pemecahannya. Jurnal Paedagogy, 7(4), 281. https://doi.org/10.33394/jp.v7i4.2941.

Basar, A. M., Islam, P. A., Nurul, S., Cikarang, F., \& Bekasi, B. (2021). Problematika Pembelajaran Jarak Jauh Pada Masa Pandemi Covid-19 (Studi Kasus di SMPIT Nurul Fajri - Cikarang Barat - Bekasi ). 2(1), 208-218. https://doi.org/10.51276/edu.v2i1.112.

Bilfaqih, Y. \& M. N. Q. (2015). Esensi Pengembangan Pembelajaran Daring. Deepublish.

Cahyani, A. dkk. (2020). Motivasi Belajar Siswa SMA pada Pembelajaran Daring di Masa Pandemi Covid19. Jurnal Pendidikan Islam, 3(1), 123-14. https://doi.org/10.37542/iq.v3i01.57.

Cucus, A., \& Aprilinda, Y. (2016). Pengembangan E-Learning Berbasis Multimedia untuk Efektivitas Pembelajaran Jarak Jauh. Explore: Jurnal Sistem Informasi Dan Telematika, 7(1). https://doi.org/10.36448/jsit.v7i1.765.

Dabbagh and B. Bannan Ritland. (2007). Online Learning: Concepts, Strategies, and Application. Education Tech Research Dev, 55, 667-669. https://doi.org/10.1007/s11423-007-9071-4.

Dewi, W. A. F. (2020). Dampak COVID-19 Terhadap Implementasi Pembelajaran Daring Di Sekolah Dasar. Jurnal Ilmu Pendidikan, 2(1), 55-61. https://doi.org/https://edukatif.org/index.php/edukatif/index

Emda, A. (2017). Kedudukan Motivasi Belajar Siswa dalam Pembelajaran. Lantanida Journal, 5(2), 93-196. https://doi.org///dx.doi.org/10.22373/lj.v5i2.2838.

Garavan, T. N., Carbery, R., Malley, G. O., \& Donnell, D. O. (2010). Understanding participation in e-learning in organizations : a large- scale empirical study of employees. International Journal of Training and Development, 14(3), 155-168. https://doi.org/10.1111/j.1468-2419.2010.00349.x.

Garbe, A., Ogurlu, U., Logan, N., \& Cook, P. (2020). Parents' Experiences with Remote Education during COVID-19 School Closures. American Journal of Qualitative Research, 4(3), 45-65. https://doi.org/10.29333/ajqr/8471.

Gumilang, G. S. (2016). Metode Penelitian Kualitatif Dalam Bidang Bimbingan Dan Konseling. Jurnal Fokus $\begin{array}{lll}\text { Konseling, } & 2(2), & 144-159 .\end{array}$ https: //ejournal.umpri.ac.id/index.php/fokus/article/download/218/155.

Gunawan, G., Suranti, N. M. Y., \& Fathoroni, F. (2020). Variations of Models and Learning Platforms for Prospective Teachers During the COVID-19 Pandemic Period. Indonesian Journal of Teacher Education, 1(2), 61-70. https://doi.org/0000-0001-8546-0150.

Hanafiah, N. \& C. (2012). Konsep Strategi Pembelajaran. PT Refika Aditama.

Herliandry, Devi ., N. M. E. S. H. K. (2020). Pembelajaran Pada Masa Pandemi Covid-19. Jurnal Pendidikan Teknologi, 22(1), 65-69. https://doi.org/10. 21009/jtp.v22i1.15286.

Jena, P. K. (2020). Impact of Pandemic COVID-19 on Education in India. International Journal of Current Research (IJCR), 12(7), 12582-12586. http://journalcra.com/article/impact-pandemic-covid-19education-india.

Kim, K. (2011). Changes In Student Motivation During Online Learning. Educational Computing Research, 44(1), 1-23. https://doi.org/10.2190/EC.44.1.a.

Koh, W. C., Naing, L., \& Wong, J. (2020). Estimating the impact of physical distancing measures in containing COVID-19: An empirical analysis. International Journal of Infectious Diseases, 100, 4249. https://doi.org/10.1016/j.ijid.2020.08.026.

Maiti, \& Bidinger. (2021). Menguak Kondisi Motivasi Belajar Siswa Dalam Pembelajaran Daring Pada Masa Pandemi Covid-19. Journal Inovasi Penelitian, 53(9), 2227-2247. https: //doi.org/10.47492/jip.v1i10.451.

Marroquín, B., Vine, V., \& Morgan, R. (2020). Mental health during the COVID-19 pandemic: Effects of stayat-home policies, social distancing behavior, and social resources. Psychiatry Research, 293(July), 113419. https://doi.org/10.1016/j.psychres.2020.113419.

Mastura dan Rustan Santaria. (2020). Dampak Pandemi Covid-19 terhadap Proses Pengajaran bagi Guru dan Siswa. Jurnal Studi Guru Dan Pembelajaran, 3(2), 289-295. https: //doi.org/10.30605/jsgp.3.2.2020.293.

Mediawati, E. (2010). Pengaruh Motivasi Belajar Mahasiswa dan Kompetensi Dosen Terhadap Prestasi Belajar. Jurnal Pendidikan Ekonomi Dinamika Pendidikan Ekonomi Dinamika Pendidikan, 5(2), 134-146. https://doi.org/10.15294/dp.v5i2.4922.

Najib, D. A. dan E. (2016). Pengaruh Penerapan Pembelajaran Bermakna (Meaningfull Learning) Pada Pembelajaran Tematik IPS Terpadu Terhadap Hasil Belajar Siswa Kelas III di MI Ahliyah IV Palembang. Jurnal PGMI, 2(1), 19-28. http://jurnal.radenfatah.ac.id/index.php/jip/article/view/1063.

Nurkholis. (2020). Dampak Pandemi Novel-Corona Virus Disiase (Covid-19) Terhadap Psikologi Dan Pendidikan Serta Kebijakan Pemerintah. Jurnal PGSD, 6(1).Nita, C. I. R., D. (2020). Analisis Motivasi Belajar Siswa Kelas IV Pada Pembelajaran Tematik Pada Masa Pandemi COVID-19 di SD 
NEGERI 5 JATIGUWI. Prosiding Seminar Nasional PGSD UNIKAMA, 4(September), 340-346. https://conference.unikama.ac.id/artikel/index.php/pgsd/article/view/525/425.

Nurkholis. (2020). Dampak Pandemi Novel-Corona Virus Disiase (Covid-19) Terhadap Psikologi Dan Pendidikan Serta Kebijakan Pemerintah. Jurnal PGSD, 6(1), 39-49. https://ejournal.umc.ac.id/index.php/JPS.

Oktiani, I. (2017). Kreativitas Guru dalam Meningkatkan Motivasi Belajar Peserta Didik. Jurnal Kependidikan, 5(2), 216-232. https://doi.org/10.24090/jk.v5i2.1939.

Pajarianto, H., Kadir, A., Galugu, N., Sari, P., \& Februanti, S. (2020). Study From Home In The Middle Of The COVID-19 Pandemic: Analysis Of Religiosity, Teacher, and Parents Support Against Academic Stress. Journal of Talent Development and Excellence, 12(2), 1791-1807. http://iratde.com/index.php/itde.

Purwanto, A. (2020). Studi Eksploratif Dampak Pandemi COVID-19 Terhadap Proses Pembelajaran Online di Sekolah Dasar. Journal Education, Psycology, Councelling, 2(1). https://ummaspul.ejournal.id/Edupsycouns/article/view/397.

Putria, H. (2020). Analisis Proses Pembelajaran Dalam Jaringan (DARING) Masa Pandemi COVID-19 pada Guru Sekolah Dasar. Jurnal BASICEDU, 4(4), 861-872. https://doi.org/10.31004/basicedu.v4i4.460.

Quezada, R. L., Talbot, C., \& Quezada-Parker, K. B. (2020). From Bricks and Mortar to Remote Teaching: A Teacher Education Program's Response to COVID-19. Journal of Education for Teaching, 46(4), 472-483. https://doi.org/10.1080/02607476.2020.1801330.

Rigianti, H. A. (2020). Kendala Pembelajaran Daring Guru Sekolah Dasar Di Kabupaten Banjarnegara. Jurnal Elementary School, 7(2), 297-302. https://doi.org/10.31316/esjurnal.v7i2.768.

Robandi, D., \& Mudjiran, M. (2020). Dampak Pembelajaran Dari Masa Pandemi Covid-19 terhadap Motivasi Belajar Siswa SMP di Kota Bukittinggi. Jurnal Pendidikan Tambusai, 4(3), 3498-3502. https://doi.org/10.31004/jptam.v4i3.878.

Sahiu, S., \& Wijaya, H. (2017). The relationship between Extrinsic Learning Motivation to Psychomotor Learning Outcomes in Grade V Christian Subjects at Zion Makassar Elementary School. Jurnal Jaffray, 15(2), 231-248. https://doi.org/10.25278/jj71.v15i2.262.

Saptono, Y. J. (2016). Motivasi dan Keberhasilan Belajar Siswa. Jurnal Pendidikan Agama Kristen, 1(1), 189-212. http://christianeducation.id/e-journal/index.php/regulafidei/article/view/9.

Smith, A. W., \& Freedman, D. O. (2020). Isolation, quarantine, social distancing and community containment: pivotal role for old-style public health measures in the novel coronavirus (2019nCoV) outbreak. Journal of Travel Medicine, 27(2). https://doi.org/10.1093/jtm/taaa020.

Sohrabi, C., Alsafi, Z., O’Neil, N., Khan, M., Kerwan, A., Al-Jabir, A., . . Aghad, R. (2020). World Health Organization declares global emergency: A review of the 2019 novel coronavirus (COVID-19). International Journal of Surgery, 71-76. https://doi.org/10.1016/j.ijsu.2020.02.034.

Song, P., \& Karako, T. (2020). COVID-19: Real-time dissemination of scientific information to fight a public health emergency of international concern. BioScience Trends, 14(1), 1-2. https://doi.org/10.5582/BST.2020.01056.

Sukiyasa, K. (2013). Pengaruh Media Animasi terhadap Hasil Belajar dan Motivasi Belajar Siswa Materi Sistem Kelistrikan Otomotif. Jurnal Pendidikan Vokasi, 4(2), 588-596. https://doi.org/10.31004/obsesi.v4i2.404.

Suprihatin, S. (2015). Upaya Guru Dalam Meningakatkan Motivasi Belajar Siswa. PROMOSI (Jurnal Pendidikan Ekonomi), 3(1), 73-82. https://doi.org/10.24127/ja.v3i1.144.

Susilo, A., Rumende, C. M., Pitoyo, C. W., Santoso, W. D., Yulianti, M., Herikurniawan, H., Sinto, R., Singh, G., Nainggolan, L., Nelwan, E. J., Chen, L. K., Widhani, A., Wijaya, E., Wicaksana, B., Maksum, M., Annisa, F., Jasirwan, C. O. M., \& Yunihastuti, E. (2020). Coronavirus Disease 2019: Tinjauan Literatur Terkini. Jurnal Penyakit Dalam Indonesia, 7(1), 45. https://doi.org/10.7454/jpdi.v7i1.415.

Susilo, Y. (2013). Peningkatan Motivasi Belajar Siswa Melalui Model Pembelajaran Kooperatif Tipe Numbered Head Together (NHT) Materi Ajar Perbandingan Dan Fungsi Trigonometri Pada Siswa Kelas X. Jurnal MATHEdunesa, 2(2).

Talevi, D., Socci, V., Carai, M., Carnaghi, G., Faleri, S., Trebbi, E., Bernardo, A. D. I., Capelli, F., \& Pacitti, F. (2020). Mental health outcomes of the CoViD-19 pandemic Gli esiti di salute mentale della pandemia di CoViD-19. Riv Psichiatr, 55(3), 137-144. https://doi.org/10.1708/3382.33569.

Titis, B., \& Sari, W. (2019). Pengaruh Durasi Belajar Terhadap Hasil Belajar Matematika Siswa Kelas 5 Ledok 006 Salatiga. Jurnal Review Pendidikan Dan Pengajaran, 2(1), 139-144. https://journal.universitaspahlawan.ac.id/index.php/jrpp/article/view/264/573.

Umar, L. M. (2020). Studi Kepustakaan Tentang Dampak Wabah Covid-19 Terhadap Kegiatan Belajar Mengajar Pada Siswa Sekolah Dasar (SD). Jurnal BK UNESA, 11(4). 
https://jurnalmahasiswa.unesa.ac.id/index.php/jurnal-bk-unesa/article/view/34440/30641.

Unaradjan, D. D. (2019). Metode Penelitian Kualitatif. Unika Atmaja Jaya.

Uno, H. B. (2011). Teori Motivasi \& Pengukurannya. Bumi Aksara.

Widlund, A., Tuominen, H., Tapola, A., \& Korhonen, J. (2020). Gendered pathways from academic performance, motivational beliefs, and school burnout to adolescents' educational and occupational aspirations. Learning and Instruction, 66(December 2019), 101299. https://doi.org/10.1016/j.learninstruc.2019.101299.

Yuliana. (2020). Corona virus diseases (Covid 19). Wellness And Healthy Magazine, 2(1), 187-192. https://doi.org/10.30604/well.95212020.

Zaharah. (2020). Impact of Corona Virus Outbreak Towards Teaching and Learning Activities in Indonesia?. Jurnal Sosial \& Budaya Syar-I, 7(3), 269-282. https://doi.org/10.15408/sjsbs.v7i3.15104.

Zhang, W., Wang, Y., Yang, L., \& Wang, C. (2020). Suspending Classes Without Stopping Learning: China's Education Emergency Management Policy in the COVID-19 Outbreak. Journal of Risk and Financial Management, 13(3), 55. https://doi.org/10.3390/jrfm13030055. 